\title{
Uterotrophic effects of relaxin related to age and estrogen receptor activation in neonatal pigs
}

\author{
Wenbo Yan ${ }^{1}$, Peter L Ryan ${ }^{2}$, Frank F Bartol ${ }^{3}$ and Carol A Bagnell ${ }^{1}$ \\ ${ }^{1}$ Department of Animal Sciences, Rutgers, The State University of New Jersey, New Brunswick, New Jersey 08901, \\ USA, ${ }^{2}$ Department of Animal and Dairy Sciences, Mississippi State University, Mississippi State, Mississippi 39762, \\ USA and ${ }^{3}$ Department of Animal Sciences, Cellular and Molecular Biosciences Program, Auburn University, \\ Auburn, Alabama 36849, USA
}

Correspondence should be addressed to C A Bagnell; Email: bagnell@aesop.rutgers.edu

\begin{abstract}
While uterotrophic effects of relaxin are well documented, the mechanism through which relaxin promotes uterine growth is incompletely understood. Studies in rats suggest that relaxin-stimulated uterine edema depends on estrogen receptor (ER) activation. Here, neonatal pigs were used to investigate the interaction between relaxin and ER signaling pathways. Gilts were treated either at birth (postnatal day (PND) 0) (study 1) before the onset of endometrial ER $\alpha$ expression, or on PND 12 (study 2) after the onset of ER $\alpha$ expression. In study 1, gilts were treated with estradiol-17 $\beta$ or porcine relaxin for two days and uteri were collected on PND 2. In study 2, PND 12 gilts were treated with a single injection of the ER antagonist ICI 182,780 (ICI) or vehicle. Two hours later, gilts were given either estradiol-17 $\beta$ or porcine relaxin for two days. When administered for two days from birth (study 1 ), neither estradiol-17 $\beta$ nor relaxin affected uterine weight or protein content. However, uterine luminal epithelial height was greater in relaxin- than in vehicle-treated gilts. In contrast, in study 2, both estradiol and relaxin increased uterine weight, protein content and uterine luminal epithelial height on PND 14. These effects were inhibited by pre-treatment with ICI in both estradiol- and relaxin-treated gilts. The results indicate that uterotrophic effects of relaxin in the neonatal pig are related to age and to both the relative presence and state of activation of the ER system in developing uterine tissues between birth and PND 14.

Reproduction (2006) 131 943-950
\end{abstract}

\section{Introduction}

Relaxin, a $6000 \mathrm{Da}$ polypeptide hormone, promotes growth of reproductive tissues. Uterotrophic actions of relaxin, first described in the rat (Steinetz et al. 1957), include both uterine water imbibition (Steinetz et al. 1957, Zarrow \& Brennan 1957) and increased uterine dry matter content associated with protein, collagen and glycogen accretion (Steinetz et al. 1957, Vasilenko et al. 1980, 1981, Vasilenko \& Mead 1987). Early studies indicating that relaxin-rich extracts promoted endometrial growth in juvenile and ovariectomized rhesus monkeys (Hisaw \& Hisaw 1964, Dallenbach-Hellweg \& Hisaw 1966) were later confirmed by work involving the purified hormone (Goldsmith et al. 2004), which showed that relaxin also stimulated endometrial angiogenesis. Consistently, relaxin administered in the peri-implantation period increased endometrial thickness in the macaque (Hayes et al. 2004). Relaxin also stimulated uterine remodeling and growth in prepubertal (Hall et al. 1990), pregnant
(Galvin et al. 1991, Min et al. 1997) and ovariectomized, steroid-treated prepubertal pigs (Hall et al. 1992).

Mechanisms regulating uterotrophic effects of relaxin are unclear. However, it is clear that some of these effects mimic those induced by estrogen. For example, like estradiol, relaxin increased expression of uterine insulin-like growth factor-I (Ohleth et al. 1997, Kowalski et al. 2004), gap junctions (Risek et al. 1995, Lenhart et al. 1999), vascular endothelial growth factor (Cullinan-Bove \& Koos 1993, Unemori et al. 1999), and uterine vascularization (Vasilenko \& Mead 1987, Cullinan-Bove \& Koos 1993). Estrogen receptors, which function classically as hormoneregulated transcription factors, can be activated both directly by estrogen and indirectly via crosstalk with peptide growth factor signaling pathways (Ignar-Trowbridge et al. 1992, Ma et al. 1994, Smith 1998). Crosstalk involving estrogen-independent, growth factor-dependent estrogen receptor (ER) activation is well documented (Smith 1998). Data indicating that pretreatment of ovariectomized rats with the ER antagonist ICl 182,780 
inhibited relaxin-induced uterine edema were interpreted to indicate that relaxin could be acting, in part, through crosstalk with the ER system (Pillai et al. 1999). Similar effects have not been documented in other species. Moreover, the extent to which uterotrophic effects of relaxin may be affected by the relative presence and/or state of ER activation in developing uterine tissues remains undefined.

In the pig, uterine development between birth (postnatal day (PND) 0) and PND 15 involves differentiation of endometrial glandular epithelium (GE) from luminal epithelium (LE) and proliferation of GE through endometrial stroma towards the developing myometrium (Tarleton et al. 1999, Bartol et al. 2006). Porcine endometrial ER architecture, defined in terms of the spatial relationships between ER-positive and ER-negative stromal and epithelial cells in situ (Tarleton et al. 2001), changes dramatically during this period. Uterine tissues are ER $\alpha$-negative at birth. However, differentiation of GE from LE shortly after birth is marked by the onset of ER $\alpha$ expression in endometrial stroma and nascent GE (Tarleton et al. 1998). Additionally, inhibition of uterine wall development and endometrial gland genesis by administration of $\mathrm{ICI} 182,780$ to gilts from birth through PND 13 (Tarleton et al. 1999) showed that $E R \alpha$ is not only a marker, but is also a mediator of endometrial development during this period. Transient $E R \alpha$ activation in neonatal gilts, induced by administration of estrogen for 14 days from birth, altered endometrial function and compromised uterine capacity for conceptus support in adults (Tarleton et al. 2003). Uterine responses to estrogen in neonatal gilts were exposure period-specific and related directly to endometrial ER architecture characteristic of the period during which exposure occurred (Spencer et al. 1993, Tarleton et al. 2001). Collectively, data indicate that ER-dependent developmental events characteristic of the period from birth through PND 14 are critical determinants of porcine uterine capacity. Available data can be interpreted to suggest that $E R \alpha$ expression patterns characteristic of the period from PND 0 through PND 14 may affect the nature of uterine tissue responses to growth factors capable of activating the ER. Recent preliminary data indicate that the neonatal porcine uterus is relaxin receptor (LGR7)-positive throughout this period (Wiley et al. 2003, Bagnell et al. 2005, Bartol et al. 2006). Thus, to the extent that the effects of relaxin may be mediated, in part, via crosstalk between LGR7 and ER signaling systems, the neonatal porcine uterus provides a valuable model with which to study these relationships, particularly as they pertain to uterine growth and endometrial programming (Bartol et al. 2006). Therefore, the objectives of this study were to determine if the effects of relaxin could be related functionally to the relative presence and/or state of activation of the ER system when administered either before or after the onset of $E R \alpha$ expression in the neonatal porcine uterus.

\section{Materials and Methods}

\section{Materials}

Purified porcine relaxin (CM-A fraction; $3000 \mathrm{U} / \mathrm{mg}$ ) was prepared at the Department of Biomedical Sciences (University of Guelph, ON, Canada) by extraction and purification from ovaries of pregnant sows (Sherwood \& O'Byrne 1974). Purity was confirmed by SDS-PAGE, which revealed a single band at approximately $6.2 \mathrm{kDa}$. The biological activity of the relaxin preparation was ascertained by inhibition of spontaneous uterine motility in vitro (Wiqvist \& Paul 1958), and immunoreactivity was verified by RIA (Porter et al. 1992). Estradiol-17 $\beta$ was purchased from Sigma-Aldrich Co. (St Louis, MO, USA). ICI 182,780 was kindly provided by Dr Alan Wakeling, Astra Zeneca Pharmaceuticals (Macclesfield, Cheshire, UK). Mouse anti-human ER $\alpha$ (Ab-15) monoclonal antibody was purchased from NeoMarkers, Inc. (Fremont, CA, USA). Horseradish peroxidase-conjugated anti-mouse secondary antibody was purchased from Santa Cruz Biotechnology, Inc. (Santa Cruz, CA, USA). Nitrocellulose membranes were obtained from Bio-Rad Laboratories (Hercules, CA, USA). The Renaissance Western Blot Chemiluminescence Reagent Plus kit was obtained from Perkin Elmer Life Sciences (Boston, MA, USA). X-Omatic films were purchased from Eastman Kodak Company (Rochester, NY, USA). All other chemicals were purchased from Sigma-Aldrich Co. and Invitrogen (Carlsbad, CA, USA), unless otherwise specified.

\section{Animals}

Yorkshire-Landrace gilts from the Swine Unit of the New Jersey Agricultural Experiment Station, Rutgers University, New Brunswick, NJ, USA and the Mississippi Agricultural and Forestry Experiment Station, Mississippi State University, Starkville, MS, USA were used in these studies. In study 1, PND 0 gilts were assigned to one of three treatment groups as follows: (1) control (C; vehicle alone; DMSO:ethanol (ETOH), 4:1 and PBS; $n=6)$; (2) estradiol-17 $\beta \quad(50 \mu \mathrm{g} / \mathrm{kg}$ body weight (BW), in DMSO:ETOH, 4:1 vehicle; given i.p. every $24 \mathrm{~h}$ for $48 \mathrm{~h}$; $n=7)$; (3) porcine relaxin $(20 \mu \mathrm{g} / \mathrm{kg} \mathrm{BW}$, in PBS; given i.m. every $6 \mathrm{~h}$ for $48 \mathrm{~h} ; n=8$ ). In study 2 , gilts were randomly assigned to begin one of six treatments on PND 12, as follows: (1) control (C; vehicle alone; $n=7$ ); (2) ICI $182,780(\mathrm{ICl} ; 1 \mathrm{mg} / \mathrm{kg}$ BW, given i.p. in DMSO:ETOH, 4:1 vehicle; given as a single injection $2 \mathrm{~h}$ prior to start of hormone treatment; $n=5)$; (3) estradiol-17 $\beta(50 \mu \mathrm{g} / \mathrm{kg}$ BW, i.p., every $24 \mathrm{~h}$ for $48 \mathrm{~h}$; $n=5$ ); (4) $\mathrm{ICl} /$ estradiol $(n=5)$; (5) porcine relaxin $(20 \mu \mathrm{g} / \mathrm{kg}$ BW, given i.m. every $6 \mathrm{~h}$ for $48 \mathrm{~h} ; n=6)$; and (6) ICl/relaxin $(n=10)$. Timing, dosage and route of $\mathrm{ICl}$ administration were based on studies in rodents (Gibson et al. 1991, Pillai et al. 1999), while those for relaxin administration were based on studies in prepubertal gilts and rodents (Hall et al. 1990, Pillai et al. 1999). In both studies, gilts were weighed 
and killed $3 \mathrm{~h}$ after the last injection on either PND 2 (study 1) or PND 14 (study 2). Each uterus was trimmed free of fat and associated ligaments and weighed. Midportions of uteri from each animal were fixed in $4.0 \%$ paraformaldehyde and the remaining tissue was frozen in liquid nitrogen and stored at $-80^{\circ} \mathrm{C}$. All procedures involving animals were reviewed and approved as appropriate by the Rutgers University Animal Care Advisory Committee (protocol \# 88-079) and the Mississippi State University Animal Care Advisory Committee (protocol \# 99-038). Procedures were conducted in accordance with the 'Guide for the Care and Use of Agricultural Animals in Agricultural Research and Teaching' (1999; Federation of Animal Science Society, Savoy, IL, USA).

\section{Protein extraction and evaluation of uterine ER expression status}

Protein content of uterine tissue was determined using procedures described previously (Ryan et al. 1996). Uterine tissues were homogenized in 5 volumes $(1 \mathrm{~g} / 5 \mathrm{ml})$ boiling lysis buffer (1\% SDS, $10 \mathrm{mM}$ Tris, $1 \mathrm{mM} \mathrm{CaCl}$, $\mathrm{pH}$ 7.4) followed by heating in a microwave (2 cycles of $5-7 \mathrm{~s}$ at high power). Samples were then sonicated and centrifuged $\left(12000 \mathrm{~g}, 4{ }^{\circ} \mathrm{C}\right)$ for $30 \mathrm{~min}$. Protein concentration was measured using a detergent-compatible protein assay kit (DC Protein Assay, Bio-Rad Laboratories). Uterine protein content was calculated based on the protein concentration and wet weight of the uterus.

To document $\mathrm{ER} \alpha$ expression status, uterine proteins $(30 \mu \mathrm{g})$ obtained from control gilts on PND 0, 2 and 14 were resolved on $12.0 \%$ Bis-Tris- $\mathrm{HCl}$-buffered polyacrylamide electrophoresis gels under reducing conditions and transferred onto nitrocellulose membranes. After blocking in $10.0 \%$ nonfat dry milk in Tris-buffered saline containing Tween-20 (TBST; $25 \mathrm{mM}$ Tris ( $\mathrm{pH} 7.5), 0.14 \mathrm{mM}$ sodium chloride $(\mathrm{NaCl}), 3 \mathrm{mM}$ potassium chloride $(\mathrm{KCl}), 0.05 \%$ Tween-20), membranes were incubated with mouse antihuman ER $\alpha$ antibody $(1: 100)$ overnight at $4{ }^{\circ} \mathrm{C}$. After washing with TBST, blots were incubated with horseradish peroxidase-conjugated anti-mouse secondary antibody $(1: 2000)$ for $1 \mathrm{~h}$ at room temperature, and bound antibodies were detected by enhanced chemiluminescence on film. Efforts to identify ER $\beta$ in neonatal porcine uterine tissue, using the same immunoblotting procedures, failed to reveal evidence for ER $\beta$ expression at the protein level.

\section{Histology}

Paraffin-embedded uteri were processed for morphometric analysis as described previously (Lenhart et al. 1998). Uterine tissue sections $(\sim 5 \mu \mathrm{m}$ thick) were stained with hematoxylin and eosin and mounted using Permount solution. Assessment of uterine luminal epithelial growth was determined by measuring the height of the epithelial layer from the apical surface to the basal surface adjacent to the stroma using an ocular micrometer with bright field microscopy (Ryan et al. 2001). Uterine tissues from 3-5 animals per treatment group were randomly selected and processed for morphometric analysis. For each animal, three sections from the mid-portion of one uterine horn were analyzed. Ten random sites were measured on each section.

\section{Statistical analysis}

All statistical analyses were performed using General Linear Models procedures (SAS 1989). For study 1, uterine wet weight and protein content data obtained from gilts on PND 2 were subjected to one-way analysis of variance in order to determine effects of treatment, using body weight as a covariate. In study 2, uterine wet weight and protein content data obtained from gilts on PND 14 were subjected to analyses of variance for a $2 \times 3$ factorial design. The statistical model considered variation associated with the main effects of $\mathrm{ICI}$ pre-treatment, hormone treatment and their interactions, with body weight as a covariate in all analyses. For analysis of uterine luminal epithelial height, data were evaluated by analysis of variance for a completely nested design. When appropriate, mean comparisons were performed using the Student-Newman-Keuls test for multiple comparisons and $P$ values are provided in the text. All quantitative data are expressed as least square means \pm standard errors (LSM \pm S.E.M.).

\section{Results}

\section{Confirmation of uterine ER expression status}

Results of an immunoblot analysis of ER $\alpha$ expression in uterine tissues obtained from control gilts on PND 0, 2 and 14 are presented in Fig. 1. Analyses confirmed, as anticipated, that $\mathrm{ER} \alpha$ protein was undetectable on PND 0. In contrast, a single $67 \mathrm{kDa}$ band corresponding to ER $\alpha$ protein was detectable for tissues obtained on both PND 2 and PND 14. The results establish that treatments were administered beginning prior to onset of $\mathrm{ER} \alpha$ expression in study 1 and after the onset of ER $\alpha$ expression in study 2.

\section{Study 1 - effects of relaxin and estradiol-17ß on uterine growth responses at PND 2}

When administered from birth, neither estradiol nor relaxin affected uterine wet weight (Fig. 2) or protein content (data not shown) as determined on PND 2. Representative photomicrographs of the uterine wall illustrating

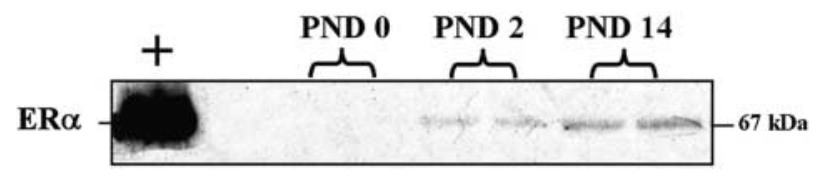

Figure 1 Representative immunoblot of ER $\alpha$ in the uterus of neonatal gilts on postnatal day (PND) 0 (birth), PND 2 and PND 14. Two animals of each age are shown. MCF-7 breast cancer cell lysate was used as a positive control $(+)$. The molecular mass $(\mathrm{kDa})$ of the protein is indicated on the right. 


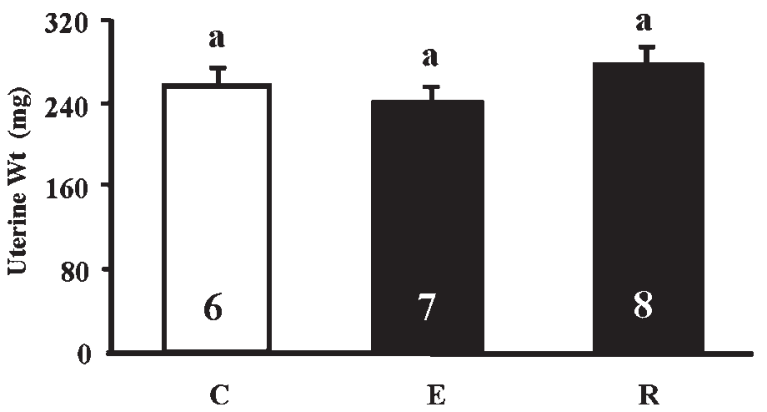

Figure 2 Effects of estradiol-17ß $(\mathrm{E})$ or relaxin $(\mathrm{R})$ on uterine wet weight in postnatal day 2 gilts. Hormone treatments were as described in the Materials and Methods section. The number of animals per group is indicated at the base of each bar. C, control. Data are expressed as LSM \pm S.E.M. Values that do not share the same letter are different as indicated in the text. The overall standard error for uterine wet weight was $13.6 \mathrm{mg}$.

the effects of relaxin and estrogen administered from birth on uterine LE height at PND 2 are shown in Fig. 3A. Morphometric analyses showed that both relaxin and estradiol treatment increased $(P<0.001)$ uterine LE height as compared with controls (Fig. 3B). Moreover, LE height in relaxin-treated gilts was greater than that observed in estradiol-treated gilts (relaxin: $39.2 \pm 0.4$ vs estradiol: $28.6 \pm 0.2 \mu \mathrm{m} ; P<0.001)$.

A

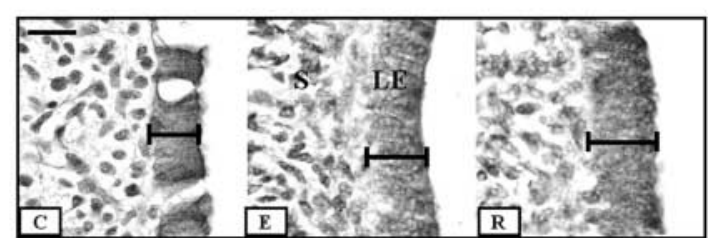

B

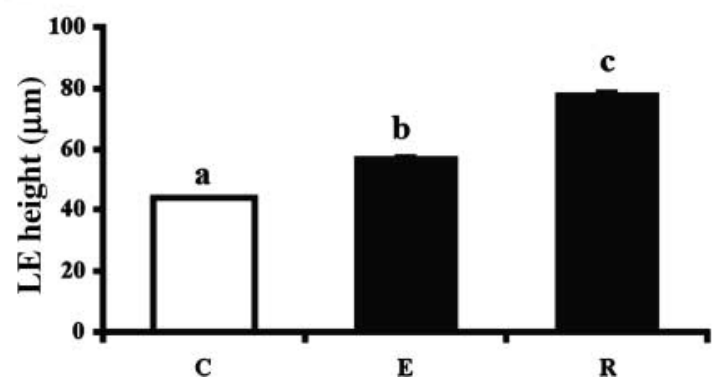

Figure 3 Uterine luminal epithelial height in postnatal day 2 gilts: effects of estradiol-17 $\beta$ (E) or relaxin (R) administration. (A) Representative photomicrographs of the uterine wall. The bar defines the luminal epithelial (LE) layer from the apical surface to the basal surface adjacent to the stroma (S). Scale bar (top left) represents $20 \mu \mathrm{m}$. (B) Quantitative analysis of changes in uterine luminal epithelial height after hormonal treatment in vivo. Hormone treatments and measurements were as described in the Materials and Methods section. C, control. Data are expressed as LSM \pm S.E.M. The overall standard error for uterine luminal epithelial height was $0.46 \mu \mathrm{m}$. Values that do not share the same letter are different as indicated in the text ( $E$ and $R$ vs C, $P<0.001$; E vs R, $P<0.001)$.

\section{Study 2 - effects of relaxin, estradiol-17 $\beta$, and ICI 182,780 on uterine growth responses at PND 14}

Data illustrating the effects of relaxin and estradiol administered for two days from PND 12 on uterine wet weight in gilts on PND 14, both with and without pre-treatment with $\mathrm{ICl}$, are presented in Fig. 4A. In contrast with results for study 1 , administration of estradiol daily for two days increased uterine weight on PND 14 relative to controls (estradiol: $1747.0 \pm 107.8$ vs control: $924.6 \pm 104.4 \mathrm{mg}$; $P<0.001)$. Likewise, relaxin treatment increased uterine weight $(1440.3 \pm 97.2 \mathrm{mg} ; P<0.001)$ to a level comparable to that in estradiol-treated gilts. Pre-treatment with $\mathrm{ICl}$, the ER antagonist, inhibited uterine weight gain in

\section{A}

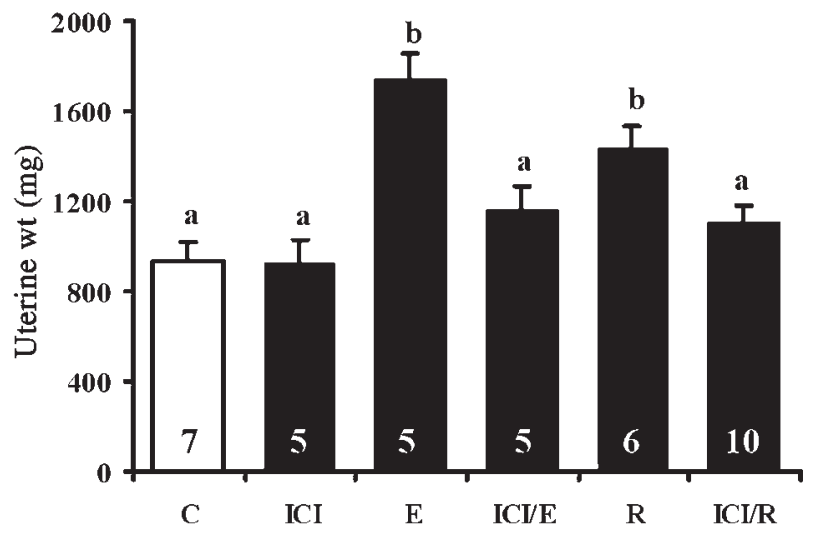

B

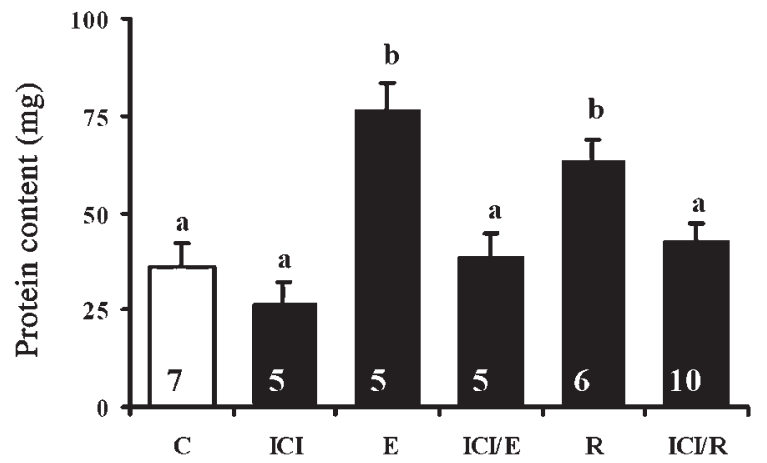

Figure 4 Uterine wet weight (A) and protein content (B) in postnatal day 14 gilts: effects of $\mathrm{ICl} 182,780(\mathrm{ICl})$ treatment prior to estradiol$17 \beta(E)$ or relaxin $(R)$ administration. Hormone treatments were as described in the Materials and Methods section. C, control. The number of animals per group is indicated at the base of each bar. Data are expressed as LSM \pm S.E.M. The overall standard error for uterine wet weight was $61.6 \mathrm{mg}$ and for uterine protein content was $4.3 \mathrm{mg}$. Values that do not share the same letter are different as indicated in the text (Fig. 4A: E vs C, $P<0.001 ; \mathrm{ICl} / \mathrm{E}$ vs $\mathrm{E}, P<0.001$; R vs $\mathrm{C}$, $P<0.001 ; \mathrm{ICl} / \mathrm{R}$ vs $\mathrm{R}, P<0.01$. Fig. $4 \mathrm{~B}$ : $\mathrm{E}$ vs $\mathrm{C}$ and $\mathrm{R}$ vs $\mathrm{C}$, $P<0.001 ; \mathrm{ICl} / \mathrm{E}$ vs $\mathrm{E}, P=0.001 ; \mathrm{ICl} / \mathrm{R}$ vs $\mathrm{R}, P=0.008)$. 
response to both estradiol $(P<0.001)$ and relaxin $(P=0.01)$ in PND 14 gilts. When administered alone, ICI did not affect uterine weight.

Data for uterine protein content on PND 14 are summarized in Fig. 4B. Again, both estradiol $(P<0.001)$ and relaxin $(P<0.001)$ treatment increased uterine protein content on PND 14 when compared with controls (control: $36.3 \pm 6.1 \mathrm{mg}$; relaxin: $63.4 \pm 5.4 \mathrm{mg}$; estradiol: $76.5 \pm 6.7 \mathrm{mg}$ ). Administered alone, $\mathrm{ICl}$ pretreatment did not affect uterine protein content. However, pretreatment with $\mathrm{ICl}$ inhibited the effects of both estradiol $(P=0.001)$ and relaxin $(P=0.008)$.

Representative photomicrographs of the uterine wall illustrating the effects of relaxin, estradiol, and $\mathrm{ICl}$, administered alone and in combination from PND 12, on uterine LE height at PND 14 are shown in Fig. 5A. Morphometric analyses showed that relaxin $(P<0.001)$, but not estradiol, increased uterine LE height when compared with vehicle-treated controls. Additionally, an interaction between hormone treatment and $\mathrm{ICl}$ pretreatment was detected (Fig. 5B). When administered alone, ICl decreased $(P<0.001)$ LE height. Pretreatment with ICI inhibited $(P<0.001)$ relaxin-induced effects on LE height and, as might be expected, also reduced $(P<0.001) \mathrm{LE}$ height when administered in advance of estrogen.

A

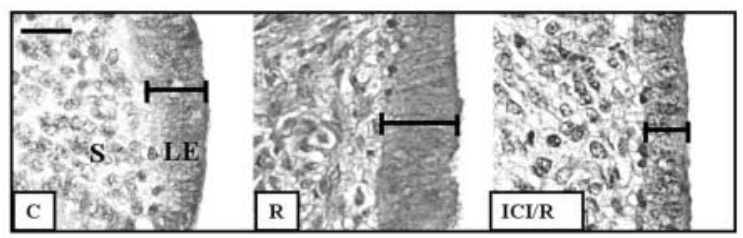

B

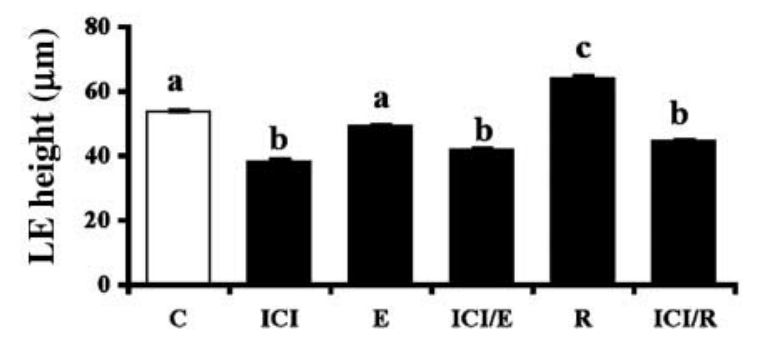

Figure 5 Uterine luminal epithelial height in postnatal day 14 gilts: effects of $\mathrm{ICl} 182,780(\mathrm{ICI})$ prior to estradiol-17 $(\mathrm{E})$ or relaxin (R) administration. (A) Representative photomicrographs of the uterine wall. The bar defines the luminal epithelial (LE) layer from the apical surface to the basal surface adjacent to the stroma (S). Scale bar (top left) represents $20 \mu \mathrm{m}$. (B) Quantitative analysis of changes in uterine luminal epithelial height after hormonal treatment in vivo. Hormone treatments and measurements are as described in the Materials and Methods section. C, control. Data are expressed as LSM \pm S.E.M. The overall standard error for uterine luminal epithelial height was $0.24 \mu \mathrm{m}$. Values that do not share the same letter are different as indicated in the text (ICI vs $\mathrm{C}, P<0.001 ; \mathrm{ICl} / \mathrm{E}$ vs $\mathrm{E}, P<0.001$; R vs $\mathrm{C}$, $P<0.001 ; \mathrm{ICl} / \mathrm{R}$ vs $\mathrm{R}, P<0.001)$.

\section{Discussion}

Although uterotrophic effects of relaxin are well documented, the mechanism through which relaxin promotes uterine growth remains elusive. This study was designed to investigate uterotrophic effects of relaxin when administered beginning either before or after the onset of ER $\alpha$ expression in the neonatal porcine uterus. Recently, evidence was presented for low uterine ER $\beta$ gene expression in adult porcine uterine tissues detected by quantitative PCR (Cardenas \& Pope 2004). Here, immunoblot analysis failed to reveal evidence for ER $\beta$ expression at the protein level in neonatal uterine tissues. However, results showed clearly that uterine ER $\alpha$ protein, undetectable by immunoblot analysis on PND 0, was present in tissues obtained on PND 2 and PND 14.

The data are consistent with earlier studies (Tarleton et al. 1998), in which temporospatial patterns of ER $\alpha$ expression were determined for porcine uterine tissues from birth through PND 15 using in situ hybridization and immunohistochemical techniques. When treatment began before the onset of $E R \alpha$ expression (PND 0), relaxin increased uterine LE height but had no effect on either uterine wet weight or protein content on PND 2. However, when treatment began after the onset of ER $\alpha$ expression (PND 12), relaxin increased all three measures of uterine growth on PND 14. Thus, the uterotrophic effects of relaxin were age-specific and more pronounced, in terms of the range of responses measured, when treatments were initiated after the onset of uterine ER $\alpha$ expression. The age-specific effects of relaxin observed here were similar to those observed for estrogen (Tarleton et al. 2001). Moreover, pretreatment of gilts with the ER antagonist ICl 182,780 inhibited tropic effects of relaxin on PND 14. Collectively, these studies suggest that the age-specific, uterotrophic effects of relaxin are developmentally regulated and that the effects of relaxin in this system are dependent, in part, on ER activation. These findings agree with research in rats, involving a similar experimental approach with $\mathrm{ICl} 182,780$, in which relaxin-stimulated uterine edema was interpreted to be ER-dependent (Pillai et al. 1999).

The present data not only support the idea that relaxin can act, in part, through the ER signaling system, but reinforce the idea that $E R \alpha$ activation is necessary to facilitate the uterotrophic effects of relaxin. In the rat, uterotrophic effects of relaxin were observed with or without prior estrogen priming (Vasilenko et al. 1980, Adams et al. 1989), although priming enhanced relaxin effects (Adams et al. 1989). Similar relationships were described for the pig (Hall et al. 1990, 1992, Galvin et al. 1991, Ohleth et al. 1997). Additionally, data generated in ovariectomized, pubertal gilts (Zaleski et al. 1995) indicating that ten days of relaxin treatment failed to promote uterine growth in the absence of ovarian steroids (estrogen or progesterone), support the view that uterotrophic actions of relaxin are at least facilitated by steroid hormone receptor 
activation. Studies involving the MCF-7 breast cancer cell line showed that relaxin could stimulate expression of an estrogen response element-luciferase reporter gene (Koos \& Pillai 2001), indicating that signaling pathways affected by relaxin can also activate the ER in the absence of estrogen.

The fact that relaxin treatments initiated both prior to and after the onset of endometrial ER $\alpha$ expression increased uterine LE height on PND 2 (study 1) and PND 14 (study 2) indicates that the porcine endometrium is relaxin-sensitive at or very shortly after birth and that endometrial relaxin receptor (LGR7) expression should be expected during this period. Tropic effects of relaxin on LE height reported here agree with earlier studies from our laboratory involving older prepubertal gilts (Ryan et al. 2001). Data indicating that cervical and vaginal luminal epithelia remained atropic in pregnant, relaxin-null as compared with wild-type mice (Zhao et al. 2000) support a role for LGR7-mediated signaling in LE development. Specific, saturable relaxin binding sites were demonstrated in uterine LE cells of pregnant gilts (Min \& Sherwood 1996). However, direct evidence of porcine uterine LGR7 expression was documented only recently in neonatal gilts, with pronounced uterine stromal LGR7 mRNA observed from birth through PND 14 (Wiley et al. 2003, Bartol et al. 2006). Studies in human and primate endometria showed specific immunolocalization of LGR7 in uterine stroma underlying LE cells (Ivell et al. 2003), a pattern also observed in the neonatal pig by PND 14 (Bartol et al. 2006). Thus, relaxin may act through its cognate receptor to promote uterine and LE growth. Still, the fact that relaxin-induced increases in LE height in PND 14 gilts were blocked by pretreatment with ICI 182,780 indicates that such effects involved ER activation. These data, taken together with evidence of uterine LGR7 expression during an established critical period for ER $\alpha$-dependent, porcine uterine development (Tarleton et al. 2003), makes the neonatal gilt a valuable model with which to investigate crosstalk between LGR7 and ER signaling systems.

Evidence that LGR7 is expressed by uterine tissues from birth and that the neonatal porcine uterus responds to exogenously administered relaxin raises the question of whether there is a natural source of relaxin in the neonatal pig. Studies in other species indicate that relaxin of maternal origin could be an important source of the hormone in the neonate by way of ingestion of colostrum and milk. Relaxin is detectable in human (Eddie et al. 1989) and canine (Goldsmith et al. 1994) colostrum and milk, and mammary tissue has been suggested as a local source of relaxin (Tashima et al. 1994). Like other peptide growth factors in milk, relaxin may contribute to early neonatal development (Burrin et al. 1997, Anderson et al. 1999). Preliminary data from this laboratory indicates that bioactive relaxin is present in porcine colostrum (Yan et al. 2005). Relationships between suckling, relaxin delivery to the neonatal circulation and reproductive tract development are under investigation.
In conclusion, data presented here indicate that neonatal uterotrophic responses to relaxin in pigs are developmentally regulated and can be related functionally to the relative presence and/or state of activation of the ER system. These findings support the hypothesis that activation of $E R \alpha$ is important for the uterine growth-promoting actions of relaxin. These studies provide a foundation for further research using the neonatal gilt as a model to study relaxin/ER interactions. The extent to which recently characterized G-protein coupled receptor 30 mediated responses to estrogen (Revankar et al. 2005, Thomas et al. 2005) may be involved in neonatal uterine responses to either estrogen or relaxin remains to be investigated.

\section{Acknowledgements}

This work was supported by USDA-NRI-99-35203-7812, USDA-NRI-2003-35203-13572, NSF EPS-0447675, the NJ Agricultural Experiment Station, and the Mississippi Agricultural and Forestry Experiment Station (MAFES). The authors acknowledge Dr Alan Wakeling, Zeneca Pharmaceuticals, Cheshire, UK, for kindly providing ICI 182,780; Dr Harold Hafs, Department of Animal Sciences, Rutgers University, New Brunswick, NJ, for statistical assistance; Ms Tamiko Yamamoto for her assistance with animal surgery and tissue collection; and the Animal Care Program at Rutgers University. The authors declare that there is no conflict of interest that would prejudice the impartiality of this scientific work.

\section{References}

Adams WC, Hanousek CA \& Frieden EH 1989 Progesterone inhibits the uterotrophic effect of relaxin in immature rats. Proceedings of the Society for Experimental Biology and Medicine 191 159-162.

Anderson JW, Johnstone BM \& Remley DT 1999 Breast-feeding and cognitive development: a meta-analysis. American Journal of Clinical Nutrition 70 525-535.

Bagnell CA, Yan W, Wiley AA \& Bartol FF 2005 Effects of relaxin on neonatal porcine uterine growth and development. Annals of the New York Academy of Sciences 1041 248-255.

Bartol FF, Wiley AA \& Bagnell CA 2006 Uterine development and endometrial programming. Reproduction Supplement 62 113-130.

Burrin DG, Davis TA, Fiorotto ML \& Reeds PJ 1997 Role of milkborne vs endogenous insulin-like growth factor I in neonatal growth. Journal of Animal Science 75 2739-2743.

Cardenas H \& Pope WF 2004 Attenuation of estrogenic effects by dihydrotestosterone in the pig uterus is associated with downregulation of the estrogen receptors. Biology of Reproduction $\mathbf{7 0}$ $297-302$

Cullinan-Bove K \& Koos RD 1993 Vascular endothelial growth factor/vascular permeability factor expression in the rat uterus: rapid stimulation by estrogen correlates with estrogen-induced increases in uterine capillary permeability and growth. Endocrinology 133 829-837.

Dallenbach-Hellweg GDA \& Hisaw FL 1966 The effect of relaxin on the endometrium of monkeys. Histological and histochemical studies. American Journal of Anatomy 119 61-71.

Eddie LW, Sutton B, Fitzgerald S, Bell RJ, Johnston PD \& Tregear GW 1989 Relaxin in paired samples of serum and milk from women after term and preterm delivery. American Journal of Obstetics and Gynecology 161 970-973.

Galvin JM, Anthony RV \& Day BN 1991 Effects of purified porcine relaxin on the uterus of gilts during early pregnancy. Animal Reproduction Science 26 293-301. 
Gibson MK, Nemmers LA, Beckman WC Jr, Davis VL, Curtis SW \& Korach KS 1991 The mechanism of ICI 164,384 antiestrogenicity involves rapid loss of estrogen receptor in uterine tissue. Endocrinology 129 2000-2010.

Goldsmith LT, Lust G \& Steinetz BG 1994 Transmission of relaxin from lactating bitches to their offspring via suckling. Biology of Reproduction 50 258-265.

Goldsmith LT, Weiss G, Palejwala S, Plant TM, Wojtczuk A, Lambert WC, Ammur N, Heller D, Skurnick JH, Edwards D et al. 2004 Relaxin regulation of endometrial structure and function in the rhesus monkey. PNAS $1014685-4689$.

Hall JA, Cantley TC, Day BN \& Anthony RV 1990 Uterotrophic actions of relaxin in prepubertal gilts. Biology of Reproduction $\mathbf{4 2}$ $769-774$.

Hall JA, Cantley TC, Galvin JM, Day BN \& Anthony RV 1992 Influence of ovarian steroids on relaxin-induced uterine growth in ovariectomized gilts. Endocrinology 130 3159-3166.

Hayes ES, Curnow EC, Trounson AO, Danielson LA \& Unemori EN 2004 Implantation and pregnancy following in vitro fertilization and the effect of recombinant human relaxin administration in Macaca fascicularis. Biology of Reproduction 71 $1591-1597$.

Hisaw FL \& Hisaw FL Jr 1964 Effect of relaxin on the uterus of monkeys (Macaca mulatta) with observations on the cervix and symphysis pubis. American Journal of Obstetrics and Gynecology 89 $141-155$.

Ignar-Trowbridge DM, Nelson KG, Bidwell MC, Curtis SW, Washburn TF, McLachlan JA \& Korach KS 1992 Coupling of dual signaling pathways - epidermal growth-factor action involves the estrogen-receptor. PNAS 89 4658-4662.

Ivell R, Balvers M, Pohnke Y, Telgmann R, Bartsch O, Milde-Langosch K, Bamberger AM \& Einspanier A 2003 Immunoexpression of the relaxin receptor LGR7 in breast and uterine tissues of humans and primates. Reproductive Biology and Endocrinology 1114.

Koos RD \& Pillai SB 2001 Intersection of the relaxin and estrogen signalling pathways in the uterus. In Relaxin 2000, pp 101-108. Eds. G Tregear, R Ivell, RA Bathgate, JD Wade. Kluwer Academic Publishers: Dordrecht, the Netherlands.

Kowalski AA, Vale-Cruz DS, Simmen FA \& Simmen RC 2004 Uterine androgen receptors: roles in estrogen-mediated gene expression and DNA synthesis. Biology of Reproduction $\mathbf{7 0}$ 1349-1357.

Lenhart JA, Downey BR \& Bagnell CA 1998 Connexin 43 gap junction protein expression during follicular development in the porcine ovary. Biology of Reproduction 58 583-590.

Lenhart JA, Ryan PL, Ohleth KM \& Bagnell CA 1999 Expression of Connexin-26, -32, and -43 gap junction proteins in the porcine cervix and uterus during pregnancy and relaxin- induced growth. Biology of Reproduction 61 1452-1459.

Ma ZQ, Santagati S, Patrone C, Pollio G, Vegeto E \& Maggi A 1994 Insulin-like growth factors activate estrogen receptor to control the growth and differentiation of the human neuroblastoma cell line SK-ER3. Molecular Endocrinology 8 910-918.

Min G \& Sherwood OD 1996 Identification of specific relaxinbinding cells in the cervix, mammary glands, nipples, small intestine, and skin of pregnant pigs. Biology of Reproduction 55 $1243-1252$

Min G, Hartzog MG, Jennings RL, Winn RJ \& Sherwood OD 1997 Evidence that endogenous relaxin promotes growth of the vagina and uterus during pregnancy in gilts. Endocrinology 138 560-565.

Ohleth KM, Lenhart JA, Ryan PL, Radecki SV \& Bagnell CA 1997 Relaxin increases insulin-like growth factors (IGFs) and IGF-binding proteins of the pig uterus in vivo. Endocrinology 138 $3652-3658$.

Pillai SB, Rockwell LC, Sherwood OD \& Koos RD 1999 Relaxin stimulates uterine edema via activation of estrogen receptors: blockade of its effects using ICI 182,780, a specific estrogen receptor antagonist. Endocrinology 140 2426-2429.
Porter DG, Ryan PL \& Norman L 1992 Lack of effect of relaxin on oxytocin output from the porcine neural lobe in vitro or in lactating sows in vivo. Journal of Reproduction and Fertility 96 $251-260$.

Revankar CM, Cimino DF, Sklar LA, Arterburn JB \& Prossnitz ER 2005 A transmembrane intracellular estrogen receptor mediates rapid cell signaling. Science 307 1625-1630.

Risek B, Klier FG, Phillips A, Hahn DW \& Gilula NB 1995 Gap junction regulation in the uterus and ovaries of immature rats by estrogen and progesterone. Journal of Cell Science $\mathbf{1 0 8}$ 1017-1032.

Ryan PL, Valentine AF \& Bagnell CA 1996 Expression of epithelial cadherin in the developing and adult pig ovary. Biology of Reproduction 55 1091-1097.

Ryan PL, Baum DL, Lenhart JA, Ohleth KM \& Bagnell CA 2001 Expression of uterine and cervical epithelial cadherin during relaxin-induced growth in pigs. Reproduction 122 929-937.

SAS 1989 In SAS/STAT User's Guide, Version 6, edn 4. Cary, NC: SAS Institute, Inc.

Sherwood OD \& O'Byrne EM 1974 Purification and characterization of porcine relaxin. Archives of Biochemistry and Biophysics $\mathbf{1 6 0}$ 185-196.

Smith CL 1998 Cross-talk between peptide growth factor and estrogen receptor signaling pathways. Biology of Reproduction $\mathbf{5 8}$ $627-632$.

Spencer TE, Bartol FF, Wiley AA, Coleman DA \& Wolfe DF 1993 Neonatal porcine endometrial development involves coordinated changes in DNA synthesis, glycosaminoglycan distribution, and ${ }^{3} \mathrm{H}$-glucosamine labeling. Biology of Reproduction 48 729-740.

Steinetz BG, Beach VL, Blye RP \& Kroc RL 1957 Changes in the composition of the rat uterus following a single injection of relaxin. Endocrinology 61 287-292.

Tarleton BJ, Wiley AA, Spencer TE, Moss AG \& Bartol FF 1998 Ovary-independant estrogen receptor expression in neonatal porcine endometrium. Biology of Reproduction 58 1009-1019.

Tarleton BJ, Wiley AA \& Bartol FF 1999 Endometrial development and adenogenesis in the neonatal pig: effects of estradiol valerate and the antiestrogen ICl 182,780. Biology of Reproduction 61 $253-263$.

Tarleton BJ, Wiley AA \& Bartol FF 2001 Neonatal estradiol exposure alters uterine morphology and endometrial transcriptional activity in prepubertal gilts. Domestic Animal Endocrinology 21 111-125.

Tarleton BJ, Braden TD, Wiley AA \& Bartol FF 2003 Estrogeninduced disruption of neonatal porcine uterine development alters adult uterine function. Biology of Reproduction 68 1387-1393.

Tashima LS, Mazoujian G \& Bryant-Greenwood GD 1994 Human relaxins in normal, benign and neoplastic breast tissue. Journal of Molecular Endocrinology 12 351-364.

Thomas P, Pang Y, Filardo EJ \& Dong J 2005 Identity of an estrogen membrane receptor coupled to a $\mathrm{G}$ protein in human breast cancer cells. Endocrinology 146 624-632.

Unemori EN, Erikson ME, Rocco SE, Sutherland KM, Parsell DA, Mak J \& Grove BH 1999 Relaxin stimulates expression of vascular endothelial growth factor in normal human endometrial cells in vitro and is associated with menometrorrhagia in women. Human Reproduction 14 800-806.

Vasilenko P \& Mead JP 1987 Growth-promoting effects of relaxin and related compositional changes in the uterus, cervix and vagina of the rat. Endocrinology 120 1370-1376.

Vasilenko P 3rd, Frieden EH \& Adams WC 1980 Effect of purified relaxin on uterine glycogen and protein in the rat. Proceedings of the Society of Experimental Biology and Medicine 163 245-248.

Vasilenko P 3rd, Adams WC \& Frieden EH 1981 Uterine size and glycogen content in cycling and pregnant rats: influence of relaxin. Biology of Reproduction 25 162-169.

Wiley AA, Bartol FF, Bathgate RA \& Bagnell CA 2003 Relaxin (LGR7) and insulin-like peptide-3 (LGR8) receptor expression in neonatal porcine uterine tissues. Biology of Reproduction $\mathbf{6 8}$ (Supplement 1) 176. 
Wiqvist N \& Paul KG 1958 Inhibition of the spontaneous uterine motility in vitro as a bioassay of relaxin. Acta Endocrinologica 29 135-146.

Yan W, Wiley AA, Bartol FF \& Bagnell CA 2005 Tissue-specific effects of relaxin on the reproductive tract of neonatal gilts. Annals of the New York Academy of Sciences 1041 132-135.

Zaleski HM, Winn RJ, Jennings RL, Dziuk PJ \& Sherwood OD 1995 Effects of relaxin administration in early gestation or prior to mating on uterine length and fetal survival in gilts. Biology of Reproduction 52 1389-1394.

Zarrow MX \& Brennan DM 1957 Increased concentration of water in uterus of the rat following treatment with relaxin. Proceedings of the Society for Experimental Biology and Medicine 95 $745-747$.

Zhao L, Samuel CS, Tregear GW, Beck F \& Wintour EM 2000 Collagen studies in late pregnant relaxin null mice. Biology of Reproduction 63 697-703.

Received 19 April 2005

First decision 22 July 2005

Revised manuscript received 5 December 2005

Accepted 3 February 2006 